\title{
Phytoplankton ecology of Sechelt Inlet, a fjord system on the British Columbia coast. II. Potentially harmful species
}

\author{
F. J. R. Taylor ${ }^{1,2}$, R. Haigh ${ }^{1}$, T. F. Sutherland ${ }^{3}$ \\ ${ }^{1}$ Department of Oceanography, and ${ }^{2}$ Department of Botany, University of British Columbia, Vancouver, British Columbia, \\ Canada V6T 1Z4 \\ ${ }^{3}$ Department of Oceanography, Dalhousie University, Halifax, Nova Scotia, Canada B3H 4J1
}

\begin{abstract}
Many temperate phytoplankton species considered harmful occur in the Sechelt Inlet system, Britsh Columbia, Canada. Some of the harmful species (Chaetoceros concavicornis, Nitzschia (Pseudonitzschia) pungens, and Dinophysis fortii) were predictable spatially and/or temporally on an annual basis. Other species (Alexandrium catenella and Heterosigma carterae) exhibited greater interannual variability and are probably influenced by cyclical events (e.g El Nino Southern Oscillation) longer than the period of this study. The ecology of $C$. concavicornis suggested a physiological adaptation to low light, enabling this diatom to live along the pycnocline in stratified water away from turbulence. Fall blooms of $C$. concavicornis appear to be a function of lower temperatures and decreasing light levels characteristic of the summer-autumn transition. N. pungens was found to occur regularly in summer and autumn; populations during the latter period were chiefly composed of $\mathrm{f}$. pungens but f. multiseries, which has been linked to domoic acid production, also occurred. One large bloom of $\mathrm{A}$. catenella occurred in late September 1989, which appeared to originate from outside the inlet complex. This PSP (paralytic shellfish poison)-producing dinoflagellate was advected into the system where it found conditions favourable to form an extensive bloom, with cell concentrations well in excess of those considered harmful $\left(1000\right.$ cells $\left.1^{-1}\right)$ down to $10 \mathrm{~m}$ throughout. This led to the highest toxicity ever recorded in British Columbia ( $31000 \mu \mathrm{g}$ per $100 \mathrm{~g}$ shellfish). Dinophysis, which produces okadaic acid, formed subsurface concentrations exceeding the reportedly harmful level of 200 cells $1^{-1}$. D. acuminata was the predominant Dinophysis species and was often abundant at 10 to $15 \mathrm{~m}$ in summer near the region of tidal turbulence. In autumn there was a regular increase in the $D$. fortii population at 5 to $10 \mathrm{~m}$ in waters of the sheltered southern end. The fish killer $H$. carterae appeared as early as March in the relatively shallow waters of the southern end. The predominant pattern, however, was summer advection of $H$. carterae into the inlet complex from outside. Further stimulation of growth occurred at the confluence of 2 inlets where nutrient flux from tidal jets was possibly augmented by the chemical conditioning from waters overlying an anoxic bottom.
\end{abstract}

KEY WORDS: Harmful phytoplankton - Chaetoceros concavicornis - Nitzschia pungens A Alexandrium catanella Dinophysis. Heterosigma carterae. Sechelt Inlet PSP

\section{INTRODUCTION}

The impact of phytoplankton on aquaculture is obvious in the case of shellfish since it constitutes the primary food source for the stock. Optimum locations for shellfish farms should therefore be in areas of high phytoplankton productivity, particularly where diatom blooms are dense and prolonged. However, the product may become contaminated by toxic substances (produced by certain species of phytoplankton) which do not harm the shellfish but become concentrated in their tissues. This leads to outbreaks of various types of shellfish poisoning (paralytic, diarrheic, amnesic, neurotoxic, hepatotoxic, etc.; see recent reviews by Shumway 1990 and Taylor 1990). Since the shellfish depurate after a period of months without further exposure to toxic blooms, there is no loss of the product if the toxicity is detected before harvesting. It is obvious that plankton monitoring can provide an early warning of impending toxicity if the harmful species 
are known. For example, domoic acid-producing diatoms have been found to cause Prince Edward Island (Canada) mussels to be toxic on a seasonal basis. A plankton monitoring program is used to detect the start of the blooms, at which time testing for the presence of domoic acid in the mussels begins, with closure as appropriate (Todd 1990). Currently in British Columbia (B.C.), Canada, shellfish are tested by the Department of Fisheries and Oceans (DFO) for the presence of saxitoxins and domoic acid. In 1989 DFO reported a record high level of saxitoxin in Sechelt Inlet (31000 $\mathrm{gg}$ per $100 \mathrm{~g}$ shellfish; Anon. 1989). The diatom initially implicated in domoic acid production, Nitzschia pungens, is common and periodically abundant in B.C. waters and so are members of the dinoflagellate genus Dinophysis, implicated elsewhere as sources of okadaic acid, leading to diarrheic shellfish poisoning. Both occur in Sechelt Inlet.

In recent years blooms of certain phytoplankton species have negatively affected farmed fish. These harmful effects ranged from direct physical damage to fish gills caused by the barbed spines of certain species of the diatom genus Chaetoceros, first seen in B.C. in 1961 (reviewed by Gaines \& Taylor 1986), to death associated with gill rupture and edema in response to substances released in the water by certain species of flagellates of the group known as chloromonads (Raphidophyceae) and dinoflagellates (Dinophyceae). The earliest record of the latter type in our region was a fish kill at the Lummi Island aquaculture project in Washington State (USA) in 1976 caused by the chloromonad Heterosigma carterae (Harrison et al. 1983, Gaines \& Taylor 1986). In 1986 the same organism led to a CA $\$ 2.5$ million loss in Sechelt Inlet. In 1989 a single bloom that covered $7000 \mathrm{~km}^{2}$ of the Strait of Georgia and Barkley Sound (observed from flights over the region) resulted in a $\$ 12$ million combined loss in B.C. and Washington State (E. A. Black pers. comm.). Heterosigma has also killed farmed fish in other temperate regions such as New Zealand (Chang et al. 1990). Other potential fish killers presently include a non-skeletal variant of the silicoflagellate Dictyocha (Thomsen \& Moestrup 1985) and a new', undescribed chloromonad flagellate which has killed fish elsewhere in B.C. (our unpubl. obs.).

Given the potential economic impact of harmful phytoplankton blooms, detailed knowledge of phytoplankton species composition and seasonal abundance should be an important consideration in determining the suitability of a particular water body for finfish aquaculture. Because of interannual variability, studies should span periods of years. Short-term variability, particularly during the spring and summer, requires that sampling should be at least every $2 \mathrm{wk}$. The level of analysis and equipment need not be very sophisti- cated although identification must be to species level. Partly because of lack of awareness and a shortage of appropriately trained personnel, this has not been the case in most aquaculture regions of the world, with what little analysis that is performed being confined to the farm sites after their establishment.

In this paper we have tried to show the utility of such analyses, both in site selection and in the understanding of bloom ecology. We selected Sechelt Inlet because (1) it is a clearly delimited body of water with distinct inputs and outputs, (2) it has received some limited oceanographic study in the past and will continue to in the future, (3) it was an area of considerable aquaculture activities (there were 15 active fish farm sites plus 12 oyster leases at the start of our study), and (4) it has been the location of both high shellfish poison and fish kills in the past.

\section{MATERIALS AND METHODS}

Field samples were collected from 6 stations in Sechelt Inlet $\left(49^{\circ} 40^{\prime} \mathrm{N}, 123^{\circ} 45^{\prime} \mathrm{W}\right)$ between May 1988 and September 1990 (Fig. 1). Samples were collected at least once a month, and twice a month from June to September. Samples were taken using the Segmented Integrated Pipe Sampler (SIPS; Sutherland et al. 1992). The 2 surface tubes were $1.5 \mathrm{~m}$ in length and the remaining 6 tubes were $3.0 \mathrm{~m}_{\mathrm{i}}$ when the 8 were connected they reached a depth of $21 \mathrm{~m}$. Each segment's content was released into a mixing chamber for sampling aboard the boat. A sample was also taken from $30 \mathrm{~m}$ with a closing bottle attached to the winch line.

Temperature and salinity of the integrated samples were measured using a thermometer and Endeco refractometer or Guildline Autosal salinometer, respectively. Occasionally, a Guildline CTD was used to obtain in situ temperature and salinity profiles. Samples of seawater from depth intervals of $0-1.5,1.5-3$, 3-6, 9-12 and 18-21 $\mathrm{m}$ were filtered through precombusted $2.5 \mathrm{~cm}$ glass fibre filters (GF/F, $0.7 \mu \mathrm{m}$ ) and frozen in $30 \mathrm{ml}$ acid-washed Nalgene polypropylene bottles for nutrient analysis at a later date; no preservatives were added. Nitrate (including nitrite; Wood et al. 1967) and ammonium were later measured on a Technicon AutoAnalyzer. Phosphate was determined using the procedure in Parsons et al. \{1984\} and measured on a Bausch and Lomb spectrophotometer

Representative microplankton subsamples (125 ml) were preserved with acidic Lugol's solution (final concentration: $1 \%$ ) and analysed using the Utermöhl technique (Hasle 1978). Depending on ambient biomass, 2.5 to $10 \mathrm{ml}$ was settled in a counting chamber for at least 12 h. Harmful species, as well as harmless species, were counted in 1 to 6 transect(s) across the 
chamber diameter ( 25 to $26 \mathrm{~mm}$ ) at $240 \times$ or on the entire chamber bottom at $95 \times$.

Contours of cell number with depth along a transect running from the mouth of Sechelt Inlet (Stn 1) to Porpoise Bay (Stn 6) were created for the 5 main harmful phytoplankters (Chaetoceros concavicornis, Nitzschia pungens, Alexandrium catenella, Dinophysis acuminata, D. fortii, and Heterosigma carterae) using the SURFER contouring and graphical package. Potential small-scale patchiness was ignored in order to see large-scale (regional) patterns. Narrows Inlet (Stn 2) and Salmon Inlet (Stn 4) were included in this straight-line transect to represent lateral inputs to the system.

Principal components analysis (PCA) was used to explore the relationships between the harmful species [log (cells $\left.\mathrm{l}^{-1}\right)$ ] and concomitant environmental variables (chlorophyll, phaeopigments, temperature, salinity, nitrate, ammonium, and phosphate). Multiple regression analysis (Model I) was thought inappropriate for the reasons outlined in Ricker (1973) and Laws \& Archie (1981); therefore, we decided to use PCA as a proxy for multiple regression (Model II). PCA is similar to the geometric mean regression for the bivariate case (see Ricker 1984) but allows central trend lines in $n$ dimensions. PCA assumes no dependency and therefore is exploratory rather than predictive. For each species at the times presented herein, the first 3 principal components were calculated (without a secondary rotation) and of the 3 components the one correlating best with the species in question was chosen to explore relationships with environmental variables.

\section{RESULTS}

The physically harmful diatom Chaetoceros concavicornis usually bloomed in late September (e.g. see Fig. 3B; based on raw cell counts ranging from 1 to 101 cells, excluding samples which did not contain this species), concurrent with the fall bloom of Chaetoceros species including $C$. convolutus (Fig. 2A). There was an unusual bloom of C. concavicornis during late June 1989 in lower Sechelt Inlet (Fig. 3A; based on raw counts of 2 to 186 cells) which occurred during a period of high temperature stratification (Fig. 2B) following bad weather, characterized by lower sunshine hours (Fig. 2C). Typi- cally $C$. concavicornis formed subsurface maxima (Fig. 3) at 5 to $10 \mathrm{~m}$. Harmful levels (>5000 cells 1 ${ }^{-1}$; Bell et al. 1974) were exceeded during the 1989 fall bloom and killed farmed salmon (Stockner 1991).

In Sechelt Inlet Nitzschia pungens exhibited maximum concentrations in fall with a smaller peak in summer (Fig. 4). It was most abundant in the upper $10 \mathrm{~m}$ of the outer region of Narrows Inlet in summer (Fig. 5A; based on raw counts of 1 to 146 cells) and in the upper $10 \mathrm{~m}$ of Porpoise Bay in early fall (Fig. 5B; based on raw counts of 1 to 199 cells). From samples of the latter period we observed a few cells of the potentially toxic f. multiseries. These summer-fall patterns were consistent for each year of the study.

Although Sechelt has some of the highest recorded levels of PSP (paralytic shellfish poison) on the B.C. coast, concentrations of Alexandrium catenella were low for most of our study period. The exception was a bloom in late September of 1989 (Fig. 4). Highest concentrations occurred at either end of Sechelt Inlet, 


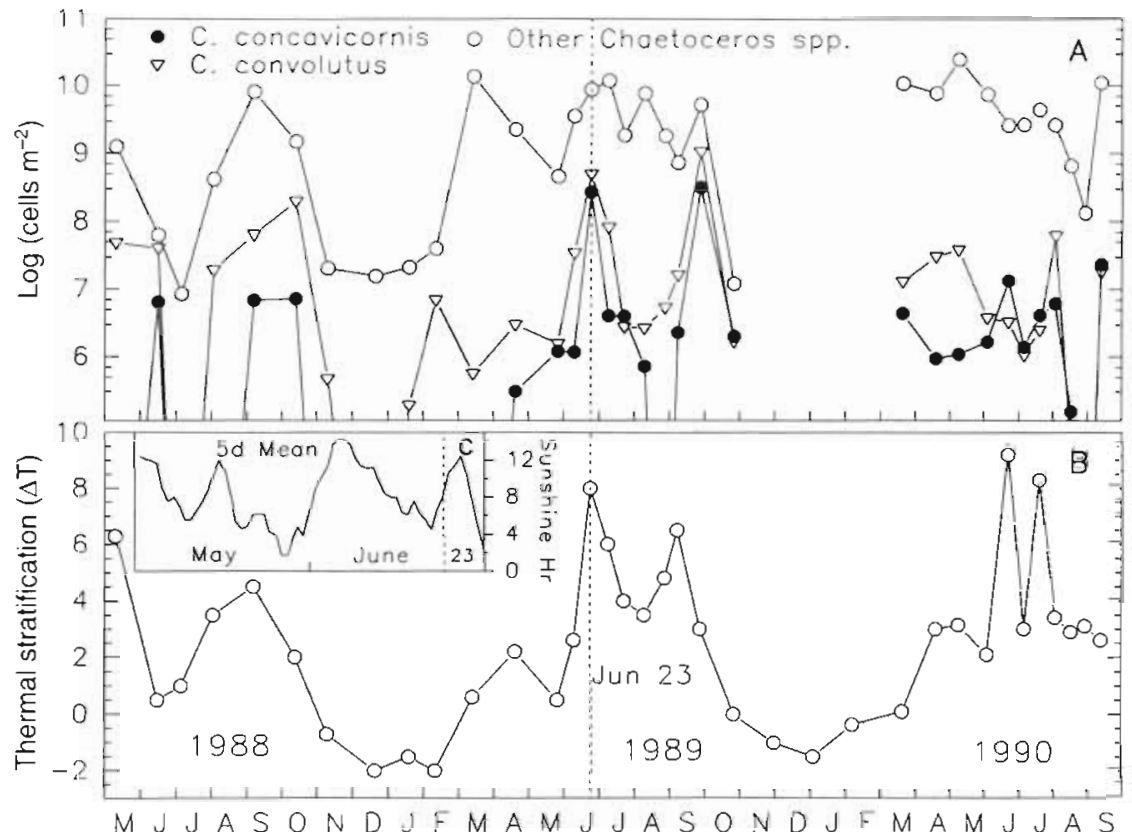

Fig. 2. (A) Successional trend of Chaetoceros concavicornis, C. convolutus, and the other Chaetoceros spp. from May 1988 to September 1990. For each station the cell concentration was integrated over $21 \mathrm{~m}_{\text {i }}$ the integrated values were averaged and expressed as the common log (note: $10^{6}$ cells $\mathrm{m}^{-2}$ $\approx 48$ cells $\mathrm{l}^{-1}$, averaged over $21 \mathrm{~m}$ ). (B) Thermal stratification, calculated as the difference in temperature between the surface and $21 \mathrm{~m}$, at Stn 5 from May 1988 to September 1990. The vertical dashed line indicates the time of the anomalous $C$. concavicornis bloom. (C) Running $5 \mathrm{~d}$ mean of sunshine hours recorded at the closest weather station to southern Sechelt Inlet for May and June 1989 though values in excess of 5000 cells $1^{-1}$ were found throughout the system in the top $5 \mathrm{~m}$ (Fig. 6; based on raw counts of 2 to 179 cells). At the mouth of the inlet A. catenella appeared to be introduced through Skookumchuck Narrows

Dinophysis was found in Sechelt Inlet from January to October, although its main growing season began in
April. Dinophysis acuminata concentrations peaked in midsummer whereas those of $D$. fortii peaked later in fall (Fig. 7A). Integrated concentrations of these 2 species exceeded 1 million cells $\mathrm{m}^{-2}\left(\approx 48\right.$ cells $\mathrm{l}^{-1}$, averaged over $21 \mathrm{~m}$ ) within the system when thermal stratification exceeded $2^{\circ} \mathrm{C}$ (Fig. 7B). Concentrations of Dinophysis spp. greater than 200 cells $1^{-1}$, thought to

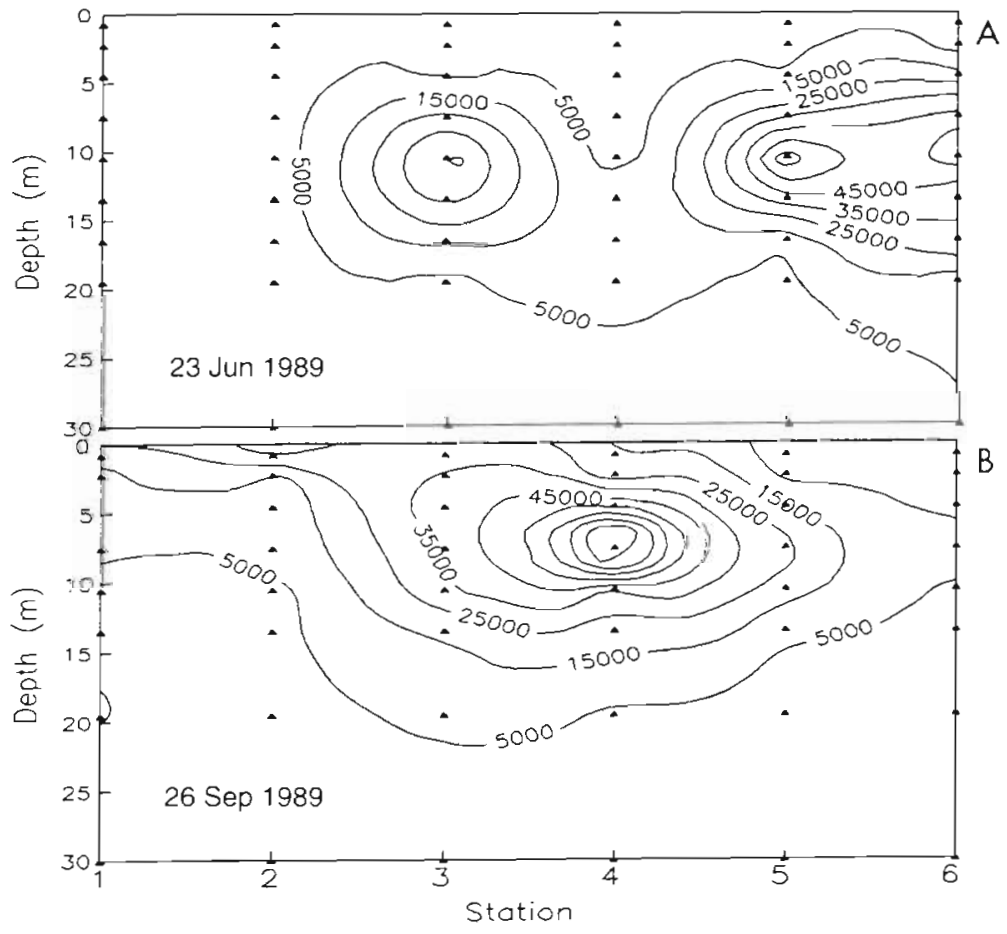

Fig. 3. Chaetoceros concavicornus. Depth profiles of abundance (cells $~^{-1}$ ) along a transect from Skookumchuck Narrows (Stn 1) to Porpoise Bay (Stn 6), assuming no small-scale patchiness. Sample depths are indicated by A. (A) Anomalous summer bloom of 1989; contours based on concentrations calculated from raw counts ranging from 0 to 1.86 cells. (B) Typical fall bloom in Salmon Inlet (Stn 4), 1989; raw counts ranged from 0 to 101 cells 
Fig. 4. Successional trend of Nitzschia pungens and Alexandrium catenella from May 1988 to September 1990. For each stathon the cell concentration was integrated over $21 \mathrm{~m}$; the integrated values were averaged and expressed as the common log (note: $10^{6}$ cells $\mathrm{m}^{-2} \approx 48$ cells $\mathrm{l}^{-1}$, averaged over $21 \mathrm{~m}$ )
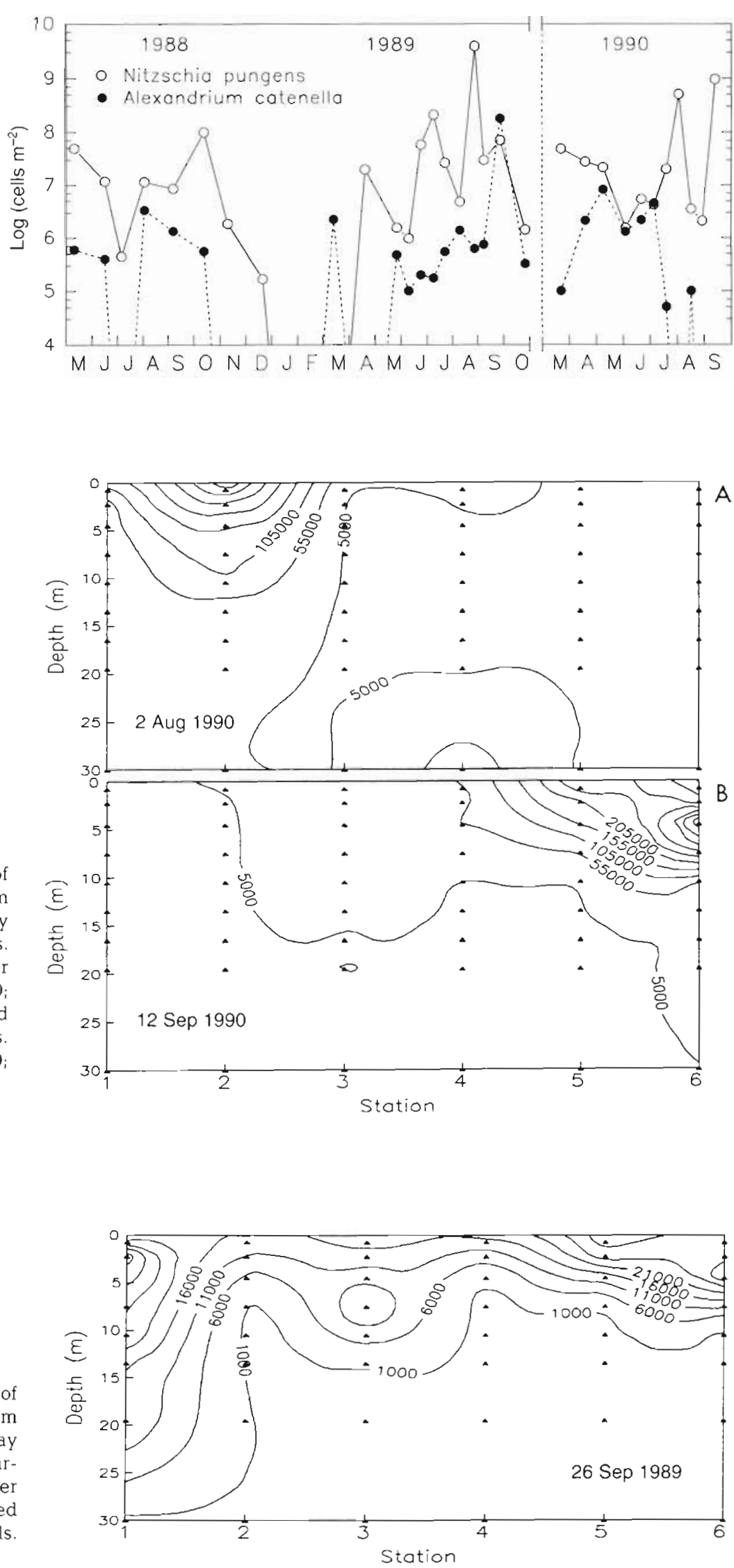

Fig. 6. Alexandrium catenella. Depth profiles of abundance (cells $\mathrm{1}^{-1}$ ) along a transect from Skookumchuck Narrows (Stn 1) to Porpoise Bay (Stn 6), assuming no small-scale patchiness, during the extensive toxic bloom of late September 1989; contours based on concentrations calculated from raw counts ranging from 0 to 179 cells. Sample depths are indicated by $\boldsymbol{A}$
Fig. 5. Nitzschia pungens. Depth profiles of abundance (cells $1^{-1}$ ) along a transect from Skookumchuck Narrows (Stn 1) to Porpoise Bay Sample depths are indicated by (A) Summer concentration, outer Narrows Inlet (Stn 2), 1990 contours based on concentrations calculated from raw counts ranging from 0 to 149 cells. raw concentration, Porpoise Bay (Stn 6),
raw ranged from 0 to 199 cells 


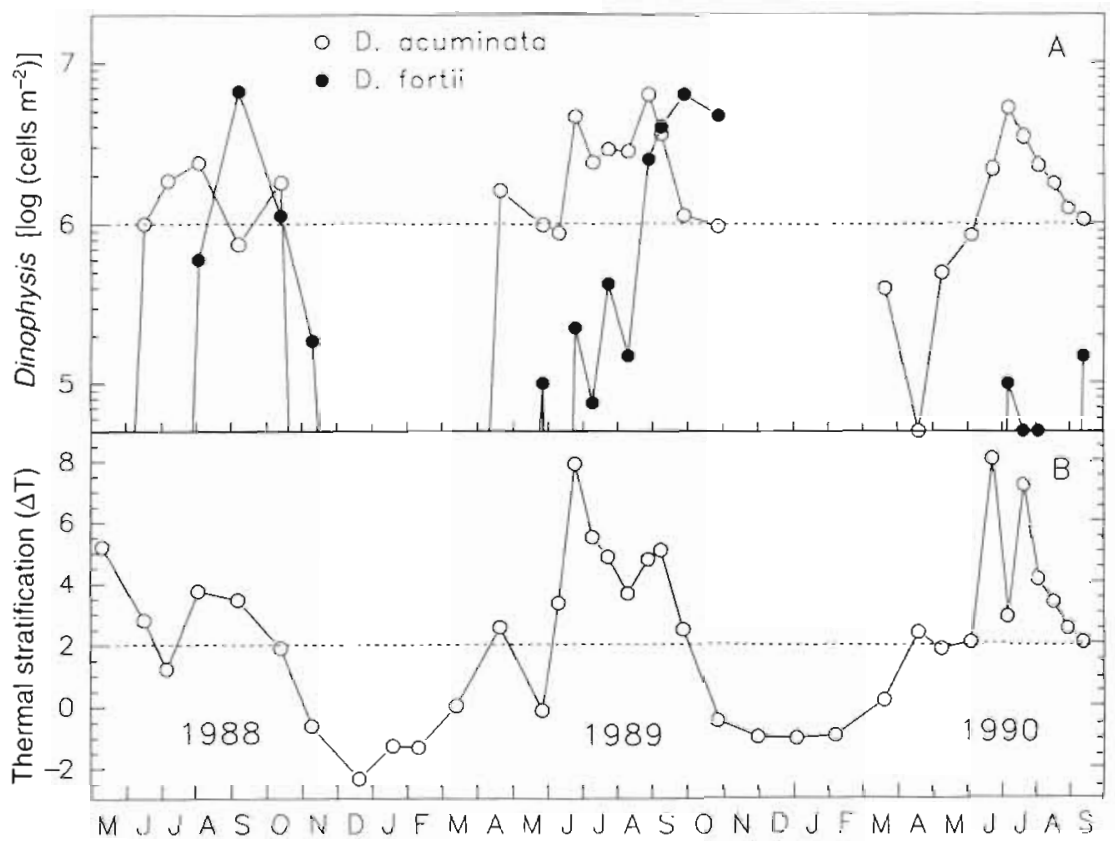

Fig. 7. (A) Successional trend of Dinophysis acuminata and $D$. fortii from May 1988 to September 1990. For each station the cell concentration was integrated over $21 \mathrm{~m}_{i}$ the integrated values were averaged and expressed as the common log (note: $10^{6}$ cells $\mathrm{m}^{-2} \approx 48$ cells $1^{-1}$, averaged over $21 \mathrm{~m}$ ). Horizontal dashed line indicates cell concentration of $10^{6} \mathrm{~m}^{-2}$. (B) Thermal stratification, calculated as the difference in temperature between the surface and $21 \mathrm{~m}$, for the Sechelt Inlet system (average of 6 stations) from May 1988 to September 1990. Horizontal dashed line indicates $\Delta \mathrm{T}=2^{\circ} \mathrm{C}$ cause shellfish intoxication leading to DSP (Diarrheic Shellfish Poisoning; Yasumoto et al. 1980, Lassus et al. 1985), could be found throughout the system with loci at various stations. The species most prevalent in the inlet complex were $D$. acuminata, $D$. norvegica, and $D$. fortii. During most of the summer $D$. acuminata dominated and formed subsurface maxima in outer
Narrows Inlet (Fig. 8A; based on raw counts of 1 to 15 cells). By the fall a subsurface population of $D$. fortij occurred in Porpoise Bay (Fig. 8B; based on raw counts of 1 to 21 cells).

Heterosigma carterae was most abundant in Sechelt Inlet from July to October (Fig. 9) but did make an appearance as early as March, in 1990, at Porpoise Bay,

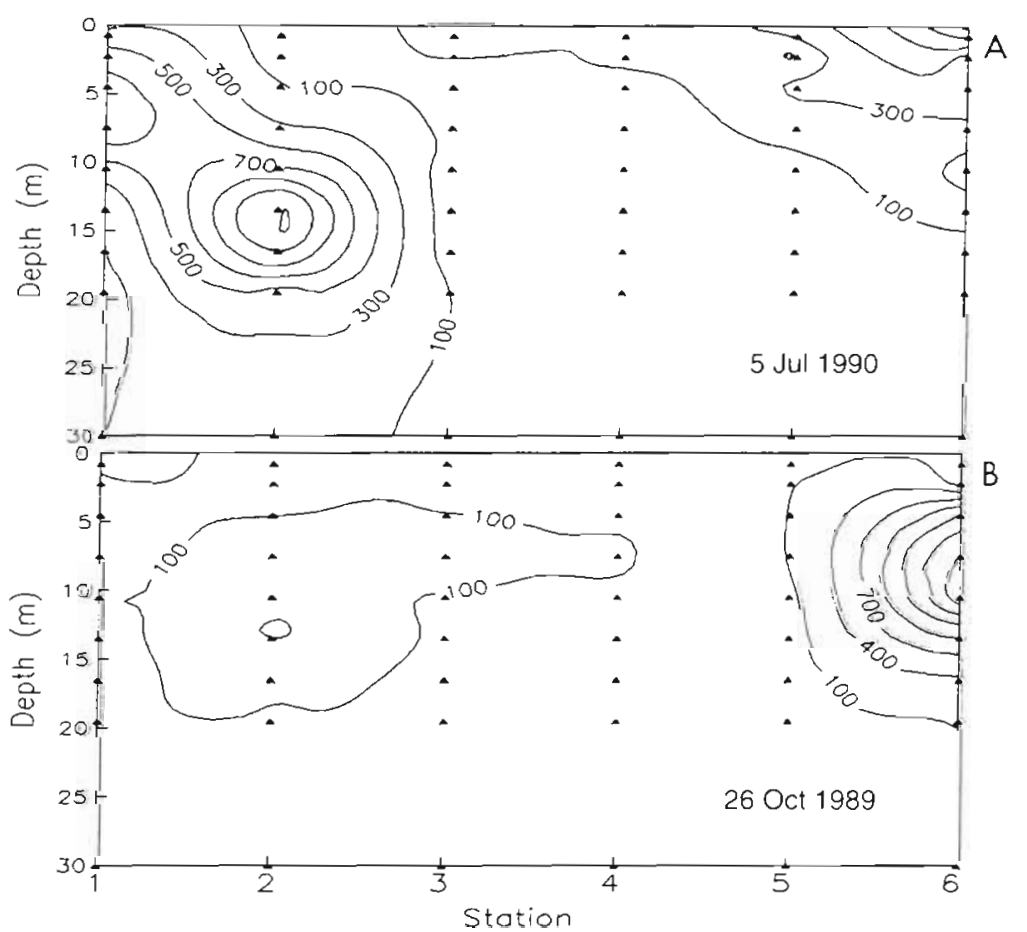

Fig. 8. Dinophysis spp. Depth profiles of abundance (cells $1^{-1}$ ) along a transect from Skookumchuck Narrows (Stn 1) to Porpoise Bay (Stn 6), assuming no small-scale patchiness. Sample depths are indicated by 4 . (A) Summer subsurface concentration of $D$. acuminata in outer Narrows Inlet, 1990; contours based on concentrations calculated from raw counts ranging from 0 to 15 cells. (B) D. fortii subsurface concentration in Porpoise Bay, late fall 1990; raw counts ranged from 0 to 21 cells 


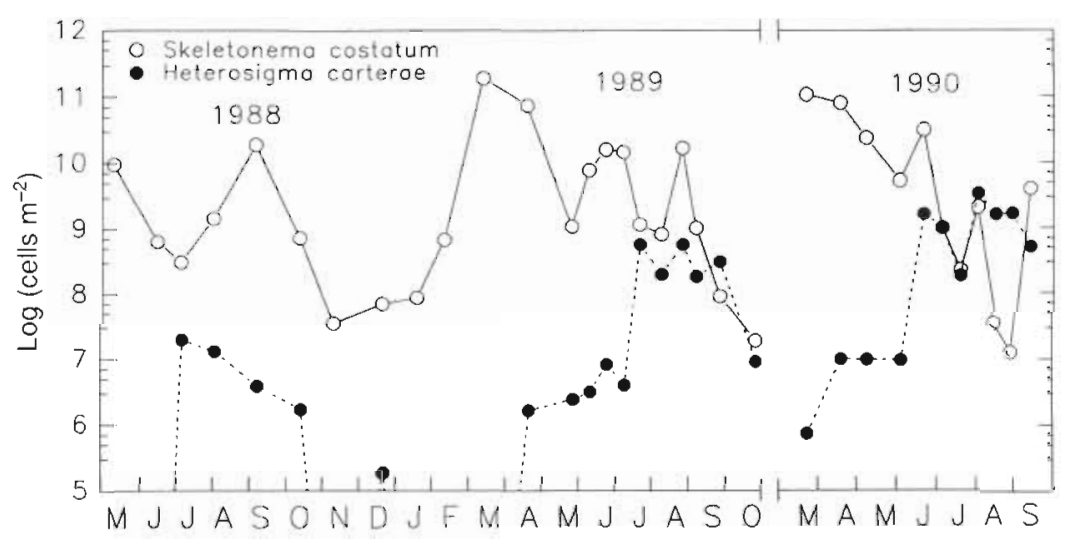

Fig. 9. Successional trend of Heterosigma carterae and Skeletonema costatum from May 1988 to September 1990. For each station the cell concentration was integrated over $21 \mathrm{~m}$; the integrated values were averaged and expressed as the common $\log$ (note: $10^{6}$ cells $\mathrm{m}^{-2} \approx 48$ cells $\mathrm{I}^{-1}$, averaged over $21 \mathrm{~m}$ ) and high $\mathrm{NH}_{4}$ : $N$. pungens (12 Sep 1990) with high chl a and low $\mathrm{NH}_{4}$; Alexandrium catenella (26 Sep 1989) with high $\mathrm{NH}_{4}$; Dinophysis acuminata (5 Jul 1990) with low chl a; and D. fortii (26 Oct 1989) with high $\mathrm{NH}_{4}$.

\section{DISCUSSION}

The potentially harmful plankton species in Sechelt Inlet, all photosynthetic, are principally members of 3 groups of phytoplankton: diatoms, dinoflagellates and chloromonads, with some potentially hazardous members of other groups such as the prymnesiomonads and silicoflagellates also present. These species are

suggesting that some cells may arise from autochthonous benthic 'seed' beds. Over the course of the study highest cell concentrations occurred at the northern end of Sechelt Inlet (Stns 1 \& 2). Successively, from 1988 to 1990 , the average $H$. carterae concentrations were an order of magnitude higher than those of the previous summer (Fig. 9). In summer there was usually advection of $H$. carterae into Sechelt Inlet through Skookumchuck Narrows (Fig. 10A: based on raw counts of 1 to 249 cells) followed by a local stimulation of this population in outer Narrows Inlet (Fig. 10B; based on raw counts of 1 to 385 cells). There was no obvious exclusion of Skeletonema costatum by $H$. carterae (Fig. 9) as suggested by Pratt (1966) until June 1990 when the latter organism reached concentrations on the order of $10^{9}$ cells $\mathrm{m}^{-2}$ $\left(\approx 47600\right.$ cells $^{-1}$, averaged over $\left.21 \mathrm{~m}\right)$.

The development of Heterosigma carterae from a benthic stage in sediments has been shown to be highly temperature dependent (Yamochi 1989). The occurrence of $H$. carterae versus temperature (Fig. 11) shows an increase in abundance until about $18^{\circ} \mathrm{C}$.

The results of the PCA are presented in Table 1. Stratified conditions were correlated with Chaetoceros concavicornis (26 Sep 89), Nitzschia pungens (2 Aug 1990), and Heterosigma carterae (21 Jun 1990 and 2 Aug 1990). The remaining species were more associated with chlorophyll and/or ammonium concentrations: C. concavicornis (23 Jun 1989) with high chl a

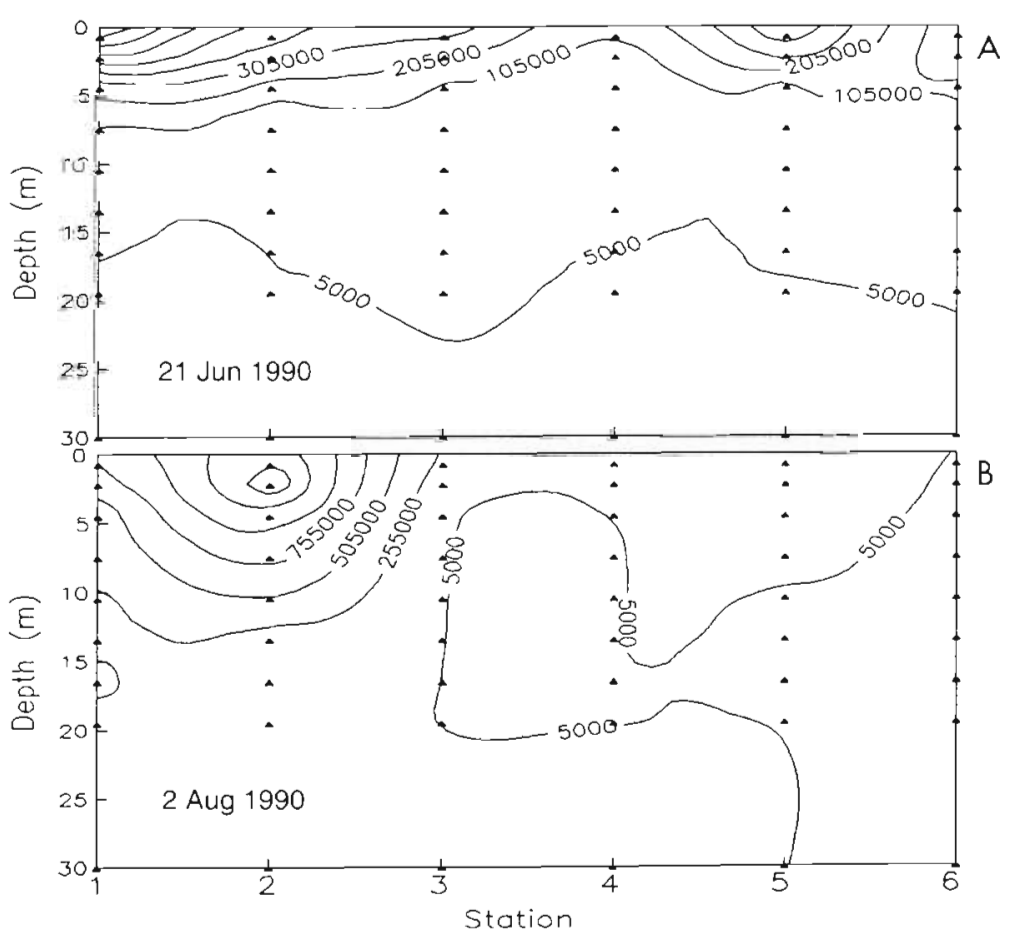

Fig. 10. Heterosigma carterae. Depth profiles of abundance (cells $\mathbf{~}^{-1}$ ) along a transect from Skookumchuck Narrows (Stn 1) to Porpoise Bay (Stn 6), assuming no small-scale patchiness. Sample depths are indicated by $\mathbf{A}$ (A) Injection of cells from Jervis lnlet in summer 1990; contours based on concentrations calculated from raw counts ranging from 0 to 249 cells.

(B) Stimulation of growth in outer Narrows Inlet of injected populations; raw counts ranged from 0 to 385 cells 


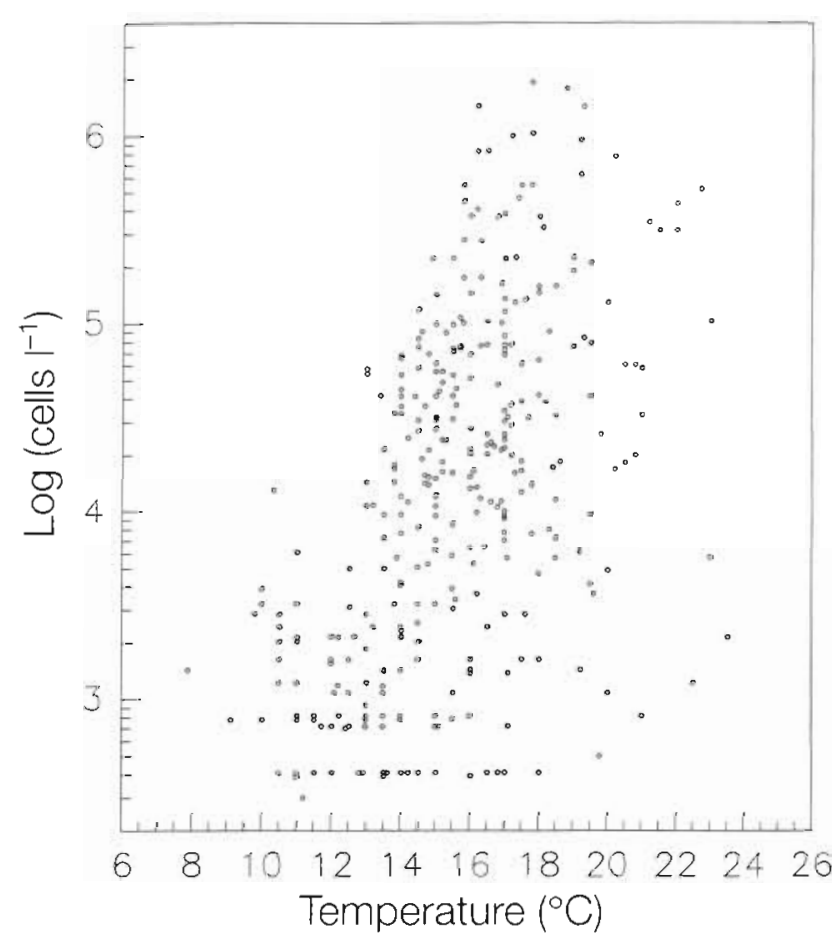

Fig. 11. Heterosigma carterae. Abundance plotted against temperature. Samples from all depths and times containing $H$. carterae were used. There is an apparent optimum at $18^{\circ} \mathrm{C}$

adjacent waters of Alaska and Washington State. The species in question have been described in detail (Gaines \& Taylor 1986). They have also been included in other regional guides (Larsen \& Moestrup 1989, Fukuyo et al. 1990, Hallegraeff 1991).

\section{Chaetoceros concavicornis and Chaetoceros convolutus}

Chaetoceros concavicornis is a chain-forming diatom which harms fish by penetrating the gill tissues with its barbed setae. Unlike the setae of other Chaetoceros species the presence of barbs causes the setae to work into the tissues. The cells are characteristically bullet shaped, 12 to $30 \mu \mathrm{m}$ wide. The setae are hollow and invaded by plastids, a characteristic of the subgenus Phaeoceros. Chains of more than 20 cells can occur but are shorter in winter when single cells also occur. $C$. concavicornis resembles $C$. convolutus, with which it has apparently been confused in earlier British Columbia reports (Bell 1961, Bell et al. 1974, Kennedy et al. 1976). C. concavicornis can be recognized under light microscopy by a narrowing of the setae as they approach the body. It also has greater barb development than $C$. convolutus and consequently is more harmful to salmon. $C$. convolutus possesses prehensors on the setae of the rounded valve (Fryxell \& Medlin 1981) which are not present on $C$. concavicornis (Evensen \& Hasle 1975; also our pers. obs.). No resting spore is known for these species and they appear to be present in the water column year-round, often relatively deep. We view both species to be opportunistic, capable of tolerating lower light levels than other Chaetoceros species (Harrison et al. 1993), perhaps due to chloroplasts in the hollow setae.

Chaetoceros concavicornis concentrations consid-

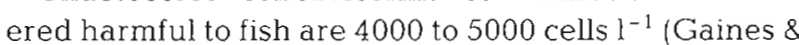
Taylor 1986); C. convolutus has been reported harmful to fish at ca $10^{5}$ chains $1^{-1}$ (Farrington 1988). Fish losses from these species have been reported from neighbouring Washington State (Horner et al. 1990, 1991) and in Sechelt Inlet (E. A. Black pers, comm.). There are indications that salmon species may differ in their sensitivity, with Atlantics being most sensitive (250 000 were lost in Washington State in 1987, worth approximately US\$0.5 million; Rensel et al. 1989, Horner et al. 1990).

In Sechelt Inlet the peak concentration of Chaetoceros concavicornis occurred during the fall bloom of

Table 1 Correlations of original variables with principal component most influenced by the harmful species Chaetoceros concavicomis, Nitzschia pungens, Alexandrium catenella, Dinophysis acuminata, D. fortii and Heterosigma carterae. Values in bold type highlight environmental variables with greatest correlation with principal component

\begin{tabular}{|c|c|c|c|c|c|c|c|c|c|}
\hline \multirow{4}{*}{$\begin{array}{l}\text { Species: } \\
\text { Date: } \\
\text { Component: } \\
\text { \% Variance: }\end{array}$} & \multicolumn{2}{|c|}{ C. concavicornis } & \multicolumn{2}{|c|}{ N. pungens } & \multirow{2}{*}{$\begin{array}{c}\text { A. catenella } \\
26 \text { Sep } 89\end{array}$} & \multirow{2}{*}{$\begin{array}{l}\text { D. acuminata } \\
5 \mathrm{Jul} 90\end{array}$} & \multirow{2}{*}{$\begin{array}{c}\text { D. fortii } \\
26 \text { Oct } 89\end{array}$} & \multicolumn{2}{|c|}{ H. carterae } \\
\hline & 23 Jun 89 & $26 \operatorname{sep} 89$ & 2 Aug 90 & $12 \operatorname{Sep} 90$ & & & & 21 Jun 90 & 2 Aug 90 \\
\hline & 1 & 1 & 1 & 2 & 3 & 3 & 3 & 1 & 1 \\
\hline & 50.4 & 52.2 & 53.5 & 23.2 & 14.2 & 14.0 & 13.7 & 57.7 & 55.9 \\
\hline Log (cells $\left.1^{-1}\right)$ & 0.748 & 0.629 & 0.717 & 0.680 & 0.757 & 0.656 & 0.693 & 0.798 & 0.774 \\
\hline Chtorophyll $a$ & 0.835 & 0.641 & 0.641 & 0.557 & 0.119 & -0.594 & -0.196 & 0.650 & 0.679 \\
\hline Phaeopigment & 0.789 & 0.399 & 0.371 & 0.488 & -0.134 & -0.160 & 0.064 & 0.706 & 0.504 \\
\hline Temperature & -0.726 & 0.722 & 0.850 & -0.476 & -0.150 & 0.369 & 0.409 & 0.853 & 0.846 \\
\hline Salmity & - & - & -0.862 & 0.501 & - & 0.041 & - & -0.872 & -0.836 \\
\hline Nitrate & 0.427 & -0.900 & -0.856 & 0.135 & 0.227 & 0.141 & 0.097 & -0.875 & -0.863 \\
\hline Ammonium & 0.815 & 0.726 & -0.392 & -0.547 & 0.491 & 0.343 & 0.496 & 0.066 & -0.347 \\
\hline Phosphate & 0.527 & -0.911 & -0.933 & 0.217 & 0.266 & -0.192 & -0.101 & -0.894 & -0.938 \\
\hline
\end{tabular}


Chaetoceros species. This pattern was also observed in the southern Strait of Georgia (Shim 1976). In the northern Strait of Georgia the maximum abundance of C. convolutus occurred in mid-August during 1986 (Haigh \& Taylor 1990), and was associated with a diverse bloom of Chaetoceros species. The $C$. concavicornis population in Sechelt Inlet on 26 September 1989 was associated with stratified conditions where $\mathrm{NH}_{4}$ was elevated, perhaps due to high heterotrophic activity (Table 1).

At low temperatures both Chaetoceros concavicornis and $C$. convolutus are capable of growing at $\mu_{\max }$ at very low irradiances (Harrison et al. 1993, grown under constant light). Highest growth rates, however, were achieved at $18^{\circ} \mathrm{C}$ when irradiance was $>50 \mu \mathrm{E} \mathrm{m}^{-2} \mathrm{~s}^{-1}$ (Harrison et al. 1993). High C. concavicornis concentrations in Sechelt Inlet (Fig. 3) were associated with a temperature range of 13 to $15^{\circ} \mathrm{C}$ at 5 to $10 \mathrm{~m}$. The combination of moderate temperatures and low light levels generally occurs in fall when waters are losing stored heat, and seasonal irradiance decreases rapidly. The anomalous peak in June 1989 is thought to be related to preceding bad weather, which introduced a successional perturbation (Haigh et al. 1992), and to periods of reduced sunshine in June (Fig. 2C). The June peak of C. concavicornis in lower Sechelt Inlet (Stns 3 \& 5) also coincided with a peak in thermal stratification (at Stn 5: Fig. 2B) and was associated with high biomass and elevated $\mathrm{NH}_{4}$ concentrations (Table 1).

On the British Columbia coast Chaetoceros concavicornis and $C$. convolutus grow best in sheltered waters away from turbulence (Albright et al. 1992). In Sechelt Inlet peak concentrations were usually subsurface (5 to $10 \mathrm{~m}$ ) in the region of the pycnocline; harmful concentrations rarely formed near the Skookumchuck tidal jet. Harmful Chaetoceros in the northern Strait of Georgia were also least abundant near the tidal jet and generally preferred stratified regions (Haigh \& Taylor 1990, 1991).

Inlets with surface water salinities below $17 \%$ are reportedly not conducive to the growth of harmful Chaetoceros (Albright et al. 1992). Experimentally, $C$. concavicornis is tolerant of salinities down to $17 \%$ while $C$. convolutus can only tolerate salinities as low as $25 \%$ (Harrison et al. 1993). Although Sechelt Inlet experiences freshwater input from the side inlets (Haigh et al. 1992), these species occur at depths which are not directly exposed to low salinity waters.

\section{Nitzschia pungens}

Nitzschia (Pseudonitzschia) pungens is a pennate diatom forming rigid chains. It ranges from 70 to 160 $\mu \mathrm{m}$ in length and 2 to $5 \mu \mathrm{m}$ in width. The striae and punctae can be seen with light microscopy but confirmation with electron microscopy is required for taxonomic certainty. Blooms of $\mathrm{f}$. multiseries off the east coast of Canada have been shown to produce domoic acid (Wright et al. 1989), an amino acid which can be accumulated in great quantities by mussels. The toxin causes intestinal distress and brain damage in humans that eat the mussels (Todd 1990). The syndrome, colled Amnesic Shellfish Poisoning (ASP), has occurred on the east coast of Canada (Subba Rao 1988, Bates et al. 1989). No cases of ASP have been recorded from the consumption of B.C. mussels although domoic acid has been found in some B.C. (DFO, Inspection Branch) and Washington State shellfish (Anon. 1991). The latter was produced by the closely related species Pseudonitzschia australis (Buck et al. 1992) which was not abundant in Sechelt Inlet.

Nitzschia pungens showed a predictable seasonal trend, blooming in the upper $10 \mathrm{~m}$ of outer Narrows Inlet in summer and in the upper $10 \mathrm{~m}$ of Porpoise Bay in fall. This spatio-temporal pattern was constant for each year of the study. In Prince Edward Island, where the potentially toxic nature of $N$. pungens was first recognized, the non-toxic f. pungens bloomed in summer and the domoic acid-producing f. multiseries became more prevalent in fall (Smith et al. 1990). Nitzschia pungens produces most domoic acid during stationary phase of growth, especially under nutrient (other than nitrate) limitation (Bates et al. 1991). In the Sechelt Inlet complex the summer populations of $N$. pungens were predominantly f. pungens and were associated with stratification (Table 1). The fall populations were also predominantly f. pungens; however, our SEM observations found that some cells were definitely f. multiseries with 4 to 5 rows of pores between the striae.

\section{Alexandrium catenella}

Alexandrium catenella has been reported from many cold-temperate areas including California, Japan, Chile and South Africa, with related forms in eastern Canada, the NE United States and Europe. It was first found in B.C. waters by Wailes (1939) as Peridinium discoides. Originally, only Alexandrium catenella was known from B.C. but since the 1960 s forms corresponding to $A$. acatenella (Prakash \& Taylor 1966) and A. tamarense (Cembella \& Taylor 1986) have also been identified from the more estuarine areas of the Strait of Georgia. The latter authors showed that these 'species' are genetic variants within a single 'species complex'; it is convenient for now to treat them as distinct forms. In Sechelt Inlet the catenella form predominated. 
Several species of Alexandrium are known to produce neurotoxins of the saxitoxin family in B.C. Over the 3 yr study period in Sechelt Inlet, $A$. catenella rarely achieved the cell concentration thought to intoxicate shellfish (1000 cells $1^{-1}$; Horner et al. 1990). However, the PSP monitoring program (DFO, Inspection Branch) recorded the highest-ever level of saxitoxin (31000 $\mathrm{gg}$ per $100 \mathrm{~g}$ shellfish) at Nine Mile Point (between Stns 4 \& 5) in October, 1989. This was caused by a bloom of $A$. catenella in late September with maximum concentrations of 35000 cells $1^{-1}$ being injected by the Skookumchuck tidal jet at 2 to $3 \mathrm{~m}$. The bloom extended throughout the upper $10 \mathrm{~m}$ (Fig. 6) of the system and presumably intoxicated shellfish in all areas. Curiously, the bloom was associated with elevated ammonium concentrations (Table 1) which was also found for the $C$. concavicornis population during the same sample time. The higher concentration of this nutrient may be solely coincidental, perhaps generated by greater heterotrophic activity. Data from the previous cruise suggest that the early formation of the bloom involved advection of $A$. catenella into the system from Jervis Inlet. Concentrations from local cyst populations in the shallow southern end of the inlet may have also contributed.

\section{Dinophysis spp.}

Many (most?) photosynthetic species of Dinophysis seem to be capable of the producing okadaic acid (Murata et al. 1982, Cembella 1989, Yasumoto 1990), a polyether derivative which, when concentrated by mussels, has caused DSP in Europe (principally Spain and The Netherlands, but also France, Ireland etc.). Recently it has been found in B.C. mussels at levels $400 \times$ the quarantine level (Boland et al. 1992), as predicted from the presence of Dinophysis earlier (Gaines \& Taylor 1986) A. D. Cembella (pers comm.) confirmed that $D$. acuminata in B.C. waters produces okadaic acid. The chief problem species in European coastal waters is D. acuminata (Kat 1983, Lassus et al. 1985 ) and in Japanese waters is D. fortii (Osaka \& Takabayashi 1985). In our waters these 2 species, along with $D$. norvegica, are the most common.

In Sechelt Inlet Dinophysis acuminata was the predominant Dinophysis species throughout the system. Concentrations of this species reached $10^{6}$ cells $\mathrm{m}^{-2}$ $\left(\approx 48\right.$ cells $\mathrm{I}^{-1}$, averaged over $\left.21 \mathrm{~m}\right)$ once the system had stratified to a $\Delta \mathrm{T}_{0-21 \mathrm{~m}}$ of $2^{\circ} \mathrm{C}$ (Fig. 7). Delmas et al. (1992) also showed a correlation between thermal stratification and Dinophysis concentrations; however, their offshore stations (France) had populations of 29 to $133 \times 10^{6}$ cells $\mathrm{m}^{-2}$ over $21 \mathrm{~m}\left\{\approx 1400\right.$ to 6300 cells $^{-1}$, averaged over $21 \mathrm{~m}$ ) once $\Delta T_{\text {thermocline }}$ reached $5^{\circ} \mathrm{C}$.
Typically Dinophysis acuminata formed subsurface concentrations in Narrows Inlet during summer (e.g. Fig. 8A), exceeding the reportedly harmful level of

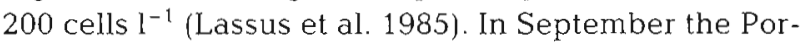
poise Bay region predictably experienced subsurface concentrations ( 5 to $15 \mathrm{~m}$ ) of $D$. fortii which exceeded 1000 cells $l^{-1}$ (e.g. Fig. 8B). On 26 October 1989 this dinoflagellate was associated with elevated ammonium levels (Table 1) which probably reflect increased heterotrophic activity. Critical cell concentrations were surpassed for the collective photosynthetic species at various locations and depths throughout the system from May to October. The length of time these levels are maintained is important; for the most part, peaks of Dinophysis were sporadic. It was only during late summer at Porpoise Bay (Stn 6) that the extent and duration of a Dinophysis population were such that DSP became a real threat. Because of their characteristic subsurface nature, surface monitoring for these species is inadequate.

\section{Heterosigma carterae}

Heterosigma carterae is the name now in use for the major fish-killing species of chloromonad in B.C. waters (formerly H. akashiwo; Taylor 1992). Since the 1960 s it has been misidentified as Olisthodiscus luteus in U.S. publications (e.g. those dealing with Narragansett Bay; Tomas 1978) and has had many experimental observations published under that name. In Scotland a similar organism which has killed fish has been referred to as 'Flagellate $X$ ' (Gowen 1984). $H$. carterae cells are small, 8 to $25 \mu \mathrm{m}$ long, ovoid, and often flattened laterally $(O$. luteus is flattened dorsoventrally). The 2 flagella emerge roughly one-third from the anterior end (see descriptions in Larsen \& Moestrup 1989, Fukuyo et al. 1990). The numerous chloroplasts are yellowish-brown to brown. Mucilage may be produced from small peripheral mucocysts (Leadbeater 1969). When preserved in Lugol's Iodine the cells have a raspberry-like appearance in which the chloroplasts are much more apparent. The species does produce a spherical benthic stage, which is difficult to recognize in sediments because of material attached to its mucoid coat. In Japanese sediments it was found that population excystment began at $10^{\circ} \mathrm{C}$ and was effectively complete at $15^{\circ} \mathrm{C}$ (Yamochi 1989).

The species is extremely halotolerant, surviving a range of 2 to $50 \%$ (Tomas 1978). Our data suggest a temperature optimum of $18^{\circ} \mathrm{C}$ (Fig 11). It migrates vertically, with a swimming speed of roughly $1 \mathrm{~m} \mathrm{~h}^{-1}$, rising to the surface during the day and descending at night (Wada et al. 1985). Because of its ability to tap higher-nutrient water at depth it does not seem likely 
to be regulated by macronutrients in a stable water column. In the Inland Sea its abundance was thought to be regulated by micronutrients (Takahashi \& Fukazawa 1982). In the Strait of Georgia blooms can last for 4 mo or more, depending on the weather (Taylor \& Haigh 1993).

The pattern of fish death due to Heterosigma can resemble that of Chattonella, with damage to gill epithelia leading to suffocation and blood changes (Okaichi 1985). There is also evidence of neurological damage (Whyte 1991). However, the nature of the substance(s) liberated is not known. A preliminary study (unpubl. obs.) suggests that fish begin to die at 12 million Heterosigma cells $1^{-1}$, but the harmful level may be much lower depending on the species of fish cultured, their size, and environmental factors.

At no time during the course of the Sechelt study did Heterosigma carterae reach cell concentrations high enough to kill fish, the highest recorded level being $1.8 \times 10^{6}$ cells $1^{-1}$. Heterosigma populations in Sechelt Inlet are perhaps influenced by a longer-term cycle such as the ENSO (El Niño Southern Oscillation) event, as suggested for Alexandrium by Erickson \& Nishitani (1985). In 1986 there was a large loss of fish due to a bloom of $H$. carterae within the Sechelt system, during which concentrations of $200 \times 10^{6}$ cells $l^{-1}$ were observed (Taylor in Dale et al. 1987). Due to aggregations by vertical migration, even higher concentrations can be achieved (e.g. $800 \times 10^{6}$ cells $1^{-1}$; Whyte 1991). Some farmers of the period thought it prudent to move their farms into the less protected waters of neighbouring Agamemnon Channel but unfortunately were hit by a massive bloom in 1989 which covered ca $7000 \mathrm{~km}^{2}$ along $750 \mathrm{~km}$ of B.C. and Washington coastline. The irony was that the bloom did not enter Sechelt Inlet even though it intruded up Jervis Inlet via Agamemnon Channel.

There is evidence that many grazers avoid Heterosigma carterae, especially at higher concentrations (Verity \& Stoecker 1982, Egloff 1986, Verity 1987, Taniguchi \& Takeda 1988). In a non-bloom situation where $H$. carterae is abundant there is usually a host of other food species from which the grazers can select. This was the situation during August 1990, the period when $H$. carterae was most abundant in our study. The oligotrichous and tintinnine ciliates were potential grazers of $H$. carterae at this time but the incidence of high nanoflagellate concentrations would have presented a more favourable alternative food source.

We found no convincing evidence of an allelopathic interaction between Heterosigma carterae and Skeletonema costatum as suggested by Pratt (1966) since $S$. costatum was usually present during peaks of $H$. carterae. However, $S$. costatum blooms occurred when H. carterae was low, preferring spring bloom rather than stratified conditions. The latter is ideal for flagellates with migrating abilities (e.g. H. carterae; Table 1). Tomas (1980) was skeptical that $H$. carterae exerted chemical inhibition and suggested that increased grazing pressure on $S$. costatum by copepods was the underlying factor. However, it is worthy of note that during any large $H$. carterae bloom a few dinoflagellate species co-occur and diatoms are virtually absent. $H$. carterae excretes or exfoliates a polysaccharideprotein complex which suppresses the growth of certain species while enhancing the growth of others (Honjo 1992), including $H$. carterae itself (Honjo 1993). This could be one reason why blooms of this flagellate are so successful, although there is probably a threshold cell concentration required before the allelopathic substance impacts species composition.

The ecology of this flagellate in Sechelt appeared to involve 2 mechanisms. The first was an early excystment of an autochthonous population from a seed bed in the Porpoise Bay region (Stn 6). The second was an introduction from Jervis Inlet of an allochthonous population which, once established within the system, thrived in the favourable environment of outer Narrows Inlet. It is was originally thought that inner Narrows Inlet might act as a seed bed (Sutherland \& Taylor 1990). Sutherland's (1991) study suggests that the sediments of inner Narrows Inlet are too anoxic to host Heterosigma carterae seed beds. Anoxic sediments, however, release sulphides which stimulate flagellate blooms (Iizuka \& Nakashima 1975) and chelate inhibitory metals (Iizuka \& Irie 1969). H. carterae grew well in outer Narrows Inlet (as did most other plankters; Haigh et al. 1992), perhaps due to the chemical conditioning from inner Narrows Inlet. We found no evidence of local stimulation of Heterosigma blooms by fish farms as was the case in the smaller and shallower Big Glory Bay, New Zealand (Pridmore \& Rutherford 1992).

\section{No appreciable eutrophication}

Many areas of the world have experienced increasing problems with phytoplankton blooms due to elevated nutrient loading (see numerous accounts in Okaichi et al. 1989) from human activity (industrialization, sewage discharge, agricultural fertilizer runoff, aquaculture, etc.). Often the affected water bodies are shallow and/or enclosed so that dilution or flushing is not great enough to maintain the normal ecological balance.

Sechelt Inlet sustained a massive Heterosigma bloom in 1986; however, it is a relatively pristine fjord surrounded for the most part by mountains and wilderness. There is no significant nutrient loading by indus- 
try or agriculture and probably only small loading from aquaculture and the town of Sechelt. Our nutrient data indicate no obvious eutrophication; the range of macronutrient $\left(\mathrm{NO}_{3}, \mathrm{NH}_{4}, \mathrm{PO}_{4}\right)$ concentrations was typical for B.C. waters (Taylor et al. 1991). Occasionally ammonium and phosphate concentrations exceeded those considered normal for upper values ( $3 \mu \mathrm{M}$ each). Spikes of ammonium occurred throughout the year but tended to be more numerous in summer and were especially prevalent near Skookumchuck Narrows (Stn 1). High ammonium may have been due to patches created by zooplankton/fish excretion, advection from Jervis Inlet, or simply an artifact of sample freezing and thawing. Phosphate and nitrate regularly reached high values in winter due to seasonal mixing.

Chlorophyll exhibited an inverse correlation with nitrate but the relationship was not linear as found by Gowen et al. (1992) for the Scottish west coast sea lochs. Our system experienced much greater ranges in chlorophyll ( 0 to 50 vs 0 to $8 \mu \mathrm{g} \mathrm{l}^{-1}$ ) and nitrate $(0$ to 30 vs 0 to $4.5 \mu \mathrm{M}$ ) than the Scottish system. The variance in the data was greatest at low nitrate which occurred just after the spring bloom (high biomass of diatoms) and throughout the summer period (lower biomass of nanoflagellates). Sechelt Inlet production is apparently not solely limited by nitrate; grazing, micronutrient limitation, light limitation, and other factors probably complicate growth dynamics.

Acknowledgements. This research was funded, in part, by NSERC grant A6137, with additional contributions from the British Columbia Ministry of Environment. We thank H. MacLean, P. O'Hara, J. Ramirez, C. Leonard, B. Fairfield, S. Lu, R. Johnson, M. Sterling, R. Pederson, L. Lee, and B. Bapte for their help in the field and/or laboratory.

\section{LITERATURE CITED}

Albright, L. J., Johnson, S., Yousif, A. (1992). Temporal and spatial distribution of the harmful diatoms Chaetoceros concavicomis and Chaetoceros convolutus along the British Columbla coast. Can. J. Fish. Aquat. Sci. 49: $1924-1931$

Anonymous (1989). 1989 summary of paralytic shellfish toxicity records in the Pacific region. Dept Fisheries \& Oceans Inspection \& Special Services Branch, Burnaby, B.C.

Anonymous (1991). Domoic acid found in Oregon and Washington shellfish. Communicable Diseases Summary 40 , No. 24. Oregon Health Division, Portland

Bates, S. S., Bird, C. J., de Freitas, A. S. W., Foxall, R., Gilgan, M., Hanic, L. A., Johnson, G. A., McCulloch, A. W., Odense, P., Pocklington, R., Quinlan, M. A., Sim, P. G., Smith, J. C., Subba Rao, D. V., Todd, E. C. D., Walter, J. A., Wright J. L. C. (1989). Pennate diatom Nitzschia pungens as the primary source of domoic acid, a toxin in shellfish from eastern Prince Edward Island, Canada. Can. J. Fish. Aquat. Sci. 46: 1203-1215

Bates, S. S., de Freitas, A. S. W., Milley, J. E., Pocklington, R., Quilliam, M. A., Smith, J. C., Worms, J. (1991). Controls on domoic acid production by the diatom Nitzschia pungens $f$ multiseries in culture: nutrients and irradiance. Can. J. Fish. Aquat. Sci. 48: 1136-1144

Bell, G. R. (1961). Penetration of spines from a marine diatom into the gill tissue of lingcod (Ophiodon elongatus). Nature 192: 279-280

Bell, G. R., Griffioen, W., Kennedy, O. (1974). Mortalities of pen-reared salmon associated with blooms of marine algae. In: Proc. Northwest Fish Culture Conf, Dec. 4-6, 1974, Seattle, WA, p. 58-60

Boland, M. P., Chen, D., Klix, H., Andersen, R. J., Taylor, F. J. R., Holmes, C. F. B. (1992). Regulation of protein phosphatases by novel marine toxins. 8th Int. Conf. on Second Messengers \& Phosphoproteins, Aug. 3-8, 1992, Glasgow, Scotland

Buck, K. R., Uttal-Cooke, L., Pilskaln, C. H., Roelke, D. L., Villac, M. C., Fryxell, G. A., Cifuentes, L., Chavez, F. P. (1992). Autecology of the diatom Pseudonitzschia australis, a domoic acid producer, from Monterey Bay, California. Mar. Ecol. Prog. Ser. 84: 293-302

Cembella, A. D. (1989). Occurrence of okadaic acid, a major diarrheic shellfish toxin, in natural populations of Dinophysis spp. from the eastern coast of North America. J. appl. Phycol. 1: 307-310

Cembella, A. D., Taylor, F. J. R. (1986). Electrophoretic variability within the Protogonyaulax tamarensis/catenella species complex: pyridine linked dehydrogenases. Biochem. Syst. Ecol. 14: 311-323

Chang, F. H., Anderson, C., Boustead, N. C. (1990). First record of a Heterosigma (Raphidophyceae) with associated mortality of cage-reared salmon in Big Glory Bay, New Zealand. N.Z. J. mar. Freshwat. Res. 24: 46-469

Dale, B., Baden, D. G., Bary, B. Mck., Edler, L., Fraga, S., Jenkinson, I. R., Hallegraeff, G. M., Okaichi, T., Tangen, K., Taylor, F. J. R., White, A. W., Yentsch, C. M., Yentsch, C. S. (1987). The problems of toxic dinoflagellate blooms in aquaculture. Proceedings from a workshop and international conference held at Sherkin Island marine station, Ireland, 8-13 June, 1987. Sherkin Island Lab., Ireland

Delmas, D., Herbland, A., Maestrini, S. Y (1992). Environmental conditions which lead to increase in cell density of the toxic dinoflagellates Dinophysis spp. in nutrient-rich and nutrient-poor waters of the French Atlantic coast. Mar. Ecol. Prog. Ser. 89: 53-61

Egloff, D. A. (1986). Effects of Olisthodiscus luteus on the feeding and reproduction of the marine rotifer, Synchaeta cecilia. J. Plankton Res. 8: 263-274

Erickson, G., Nishitani, L. (1985). The possible relationship of El Niño/Southern Oscillation events to interannual variation in Gonyaulax populations as shown by records of shellfish toxicity. In: Wooster, W. S., Fluharty. D. L. (eds.) El Niño: Niño efferts in the eastern subarctic Pacific Ocean. Washington Sea Grant, Seattle

Evensen, D. L., Hasle, G. R. (1975). The morphology of some Chaetoceros (Bacillariophyceae) species as seen in the electron microscopes. In: Simonsen, R. (ed.) Third Symposium on Recent and fossil marine Diatoms, Kiel, September 9-13, 1974. Proceedings. Royal octavo VIII. Beih. Nova Hedwigia 53: 153-184

Farrington, C. W. (1988). Mortality and pathology of juvenile chinook salmon (Oncorhynchus tshawytscha) and chum salmon (Oncorhynchus keta) exposed to cultures of the marine diatom Chaetoceros convolutus. M.Sc. thesis, University of Alaska-Southeast, Juneau

Forbes, J. R., Denman, K. L. (1991). Distribution of Nitzschia pungens in coastal waters of British Columbia. Can. J. Fish. Aquat. Sci. 48: 960-967 
Fryxell, G. A., Medlin, L. K. (1981). Chain forming diatoms: evidence of parallel evolution in Chaetoceros. Cryptogamie: Algologie 1: 3-29

Fukuyo, Y., Takano, H., Chihara, M., Matsuoka, K. (eds.) (1990). Red tide organisms in Japan - an illustrated taxonomic guide. Uchida Rokakuho, Tokyo

Gaines, G., Taylor, F. J. R. (1986). A mariculturist's guide to potentially harmful marine phytoplankton of the Pacific coast of North America. Inf. Rep. 10, Marine Resources Section, Fisheries Branch, British Columbia Ministry of Environment, Victoria

Gowen, R. J. (1984). A final report for the Highlands and Islands Development Board. Scottish Marine Biological Ass., Dunstaffnage Marine Research Laboratory

Gowen, R. J., Tett, P., Jones, K. J. (1992). Predicting marine eutrophication: the yield of chlorophyll from nitrogen in Scottish coastal waters. Mar. Ecol. Prog. Ser. 85: 153-161

Haigh, R., Taylor, F. J. R. (1990). Distribution of potentially harmful phytoplankton species in the northern Strait of Georgia, British Columbia. Can. J. Fish. Aquat. Sci. 47: $2339-2350$

Haigh, R., Taylor, F. J. R. (1991). Mosaicism of microplankton communities in the northern Strait of Georgia, British Columbia. Mar. Biol. 110: 301-314

Haigh, R., Taylor, F. J. R., Sutherland, T. F. (1992). Phytoplankton ecology of Sechelt Inlet, a fjord system on the British Columbia coast. I. General features of the nanoand microplankton. Mar. Ecol. Prog. Ser. 89: 117-134

Hallegraeff, G. M. (1991). Aquaculturists' guide to harmful Australian microalgae. CSIRO Division of Fisheries, Hobart

Harrison, P. J., Fulton, J. D., Taylor, F. J. R., Parsons, T. R. (1983). Review of the biological oceanography of the Strait of Georgia: pelagic environment. Can. J. Fish. Aquat. Sci. 40: $1064-1094$

Harrison, P. J., Thompson, P. A., Guo, M., Taylor, F. J. R. (1993). Effects of light, temperature and salinity on the growth rate of harmful marine diatoms, Chaetoceros convolutus and $C$. concavicornis, that kill netpen salmon. J. appl. Phycol. 5: 259-265

Hasle, G. R. (1978). Using the inverted microscope. In: Sournia, A. (ed.) Phytoplankton manual. Monographs on Oceanographic Methodology 6. UNESCO, Paris, p. 191-196

Honjo, T (1992). Harmful red tides of Heterosigma akashiwo. In: Svrjcek, R. S. (ed.) Control of disease in aquaculture. NOAA tech. Rep. 111:27-32

Honjo, T. (1993). Overview on bloom dynamics and physiological ecology of Heterosigma akashiwo. In: Smayda, T. J., Shimizu, Y. (eds.) Toxic phytoplankton blooms in the sea. Elsevier Sci. Publ., Amsterdam, p. 33-41

Horner, R. A., Postel, J. R., Rensel, J. E. (1990). Noxious phytoplankton blooms in western Washington waters, a review. In: Granéli, E., Sundström, B., Edler, L., Anderson, D. M. (eds.) Toxic marine phytoplankton. Elsevier, New York, p. 171-176

Horner, R., Rines, J. E. B., Stockner, E. (1991). Chaetoceros convolutus Castracane, Chaetoceros concavicornis Mangin and the mortality of pen-reared salmon in Pacific Northwest waters. In: Smayda, T. J. (ed.) Fifth Int. Conf. on Toxic Marine Phytoplankton, Oct. 28 - Nov. 1, 1991, Newport, RI, Abstracts, p. 60

Iizuka, S., Irie, H. (1969). Anoxic status of bottom waters and occurrences of Gymnodinium red water in Omura Bay. Bull. Plankton Soc. Jap. 16: 99-115

Iizuka, S., Nakashima, T. (1975). Response of red tide organisms to sulphide. Bull. Plankton Soc. Jap. 22: 27-32

Kat, M. (1983). Dinophysis acuminata blooms in the Dutch coastal area related to diarrhetic mussel poisoning in the
Dutch Waddensea. Sarsia 68: 81-84

Kennedy, W. A., Shoop, C. T., Griffioen, W., Solmie, A. (1976) The 1974 crop of salmon reared on the Pacific Biological Station experimental fishfarm. Can. Fish. Mar. Serv. Tech. Rep. 612

Larsen, J., Moestrup, O. (1989). Guide to potentially toxic marine algae. The Fish Inspection Service, Ministry of Fisheries, June 1989, Copenhagen

Lassus, P., Boudouil, M., Truquet, I., Truquet, P., leBaut, C., Pierre, M. J. (1985). Dinophysis acuminata distribution and toxicity along the southern Brittany coast (France): correlation with hydrological parameters. In: Anderson, D. M., White, A. W., Baden, D. G. (eds.) Proc. 3rd Int. Conf. on Toxic Dinoflagellate Blooms. Elsevier, New York, p. $154-164$

Laws, E. A., Archie, J. W. (1981). Appropriate use of regression analysis in marine biology. Mar. Biol. 65: 13-16

Leadbeater, S. (1969). A fine structural study of Olisthodiscus luteus Carter. Br. Phycol. J. 4: 3-17

Murata, M., Shimitani, M., Ashima, Y., Yasumoto, T. (1982). Isolation and structural elucidation of the causative toxin of the diarrhetic shellfish poisoning. Bull. Jap. Soc. scient. Fish. 48: 549-552

Okaichi, T. (1985). Fish kills due to the red tides of Chattonella. Bull. mar. Sci. 37: 772

Okaichi, T., Anderson, D. M., Nemoto, T. (1989). Red tides: biology, environmental science, and toxicology. Elsevier, New York

Osaka, K., Takabayashi, N. (1985). Annual change in distribution of the toxic dinoflagellate Dinophysis fortii along the coast of northern Japan. Bull. mar. Sci. 37: 773

Parsons, T R., Maita, Y., Lalli, C. M. (1984). A manual of chemical and biological methods for seawater analysis. Pergamon Press, Oxford

Prakash, A., Taylor, F. J. R. (1966). A 'red water' bloom of Gonyaulax acatenella in the Strait of Georgia and its relation to paralytic shellfish toxicity. J. Fish. Res. Bd Can. 23: $1265-1270$

Pratt, D. M. (1966). Competition between Skeletonema costatum and Olisthodiscus luteus in Narragansett Bay and in culture. Limnol. Oceanogr. 11: 447-455

Pridmore, R. D., Rutherford, J. C. (1992). Modelling phytoplankton abundance in a small enclosed bay used for salmon farming. Aquacult. Fish. Mgmt 23: 525-542

Rensel, J. E., Horner, R. A., Postel, J. R. (1989). Effects of phytoplankton blooms on salmon aquaculture in Puget Sound, Washington: initial research. NW environ. J. 5: $53-69$

Ricker, W. E. (1973). Linear regressions in fishery research. J. Fish. Res. Bd Can. 30: 409-434

Ricker, W. E. (1984). Computation and uses of central trend lines. Can. J. Zool. 62: 1897--1905

Shim, J. H. (1976). Distribution and taxonomy of planktonic marine diatoms in the Strait of Georgia, B.C. Ph.D. thesis, University of British Columbia, Vancouver

Shumway, S. E. (1990). A review of the effects of algal blooms on shellfish and aquaculture. J. Wld Aquacult. Soc. 21: 65

Smith, J. C., Odense, P., Angus, R., Bates, S., Bird, C., Cormier, P., de Freitas, A., Leger, C., O'Neil, D., Pauley, K. (1990). Domoic acid levels in field and laboratory populations of Nitzschia pungens forma multiseries and Nitzschia pungens forma pungens. Bull. Aquacult. Ass. Can. 90: $27-31$

Stockner, E. (1991). The phytoplankton watch program in British Columbia. In: Forbes, J. R. (ed.) Pacific coast research on toxic marine algae. Can. Tech. Rep. Hydrogr. Ocean Sci. 135: 63-64 
Subba Rao, D. V (1988). Domoic acid - a neurotoxic amino acid produced by the marine diatom Nitzschia pungens in culture. Can. J. Fish. Aquat. Sci. 45: 2073-2079

Sutherland, T. F. (1991). Phytoplankton succession and resting stage occurrence in three regions in Sechelt Inlet, British Columbia. M.Sc. thesis, University of British Columbia, Vancouver

Sutherland, T. F., Taylor, F. J. R. (1990). Are harmful flagellate blooms in Sechelt Inlet, B.C., autochthonous? Bull. Aquacult. Ass. Canada 90-4: 22-26

Sutherland, T F., Leonard, C., Taylor, F. J. R. (1992). A segmented pipe sampler for integrated profiling of the upper water column. J. Plankton Res. 14:915-923

Takahashi, M., Fukazawa, N. (1982). A mechanism of 'redtide' formation. II. Effect of selective nutrient stimulation on the growth of different phytoplankton species in natural water. Mar. Biol. 83: 255-261

Taniguchi, A., Takeda, Y. (1988). Feeding rate and behavior of the tintinnid ciliate Favella taraikaensis observed with a high speed VTR system. Mar. microb. Food Webs 3: $21-34$

Taylor, F. J. R. (1990). Red tides, brown tides and other harmful algal blooms: the view into the 1990's. In: Granéli, E., Sundstrom, B., Edler, L., Anderson, D. M. (eds.) Toxic marine phytoplankton. EIsevier, New York, p. 527-533

Taylor, F. J. R. (1992). The taxonomy of harmful marine phytoplankton. G. Bot. Ital. 126: 209-219

Taylor, F. J. R., Haigh, R. (1993). The ecology of fish-killing blooms of the chloromonad flagellate Heterosigma in the Strait of Georgia and adjacent waters. In: Smayda, T J., Shimizu, Y (eds.) Toxic phytoplankton blooms in the sea. Elsevier, New York, p. 705-710

Taylor, F. J. R., Haigh, R., Sutherland, T F., Ramirez, J. A. (1991). Final report of the harmful algal research project in Sechelt Inlet, British Columbia, 1988-1990. Report prepared for the British Columbia Ministry of Environment, Vancouver

Thomsen, H. A., Moestrup, O. (1985). Is Distephanus speculum a fish-killer? A report on an unusual algal bloom from Danish coastal waters. Bull. mar. Sci. 37: 778

Todd, E. C. D. (1990). Amnesic shellfish poisoning - a new seafood toxin syndrome. In: Granéli, E., Sundström, B., Edler, L., Anderson, D. M. (eds.) Toxic marine phytoplankton. Elsevier, New York, p. 509-511

Tomas, C.R. (1978). Olisthodiscus luteus (Chrysophyceae). I.
Effects of salinity and temperature on growth, motility and survival. J. Phycol. 14: 309-313

Tomas, C. R. (1980). Olisthodiscus luteus (Chrysophyceae). V Its occurrence, abundance and dynamics in Narragansett Bay, Rhode Island. J. Phycol. 16:157-166

Verity, P. G. (1987). Abundance, community composition, size distribution, and production rates of tintinnids in Narragansett Bay, Rhode Island. Estuar. coast. Shelf Sci. 24: $671-690$

Verity, P. G., Stoecker, D. (1982). Effects of Olisthodiscus luteus on the growth and abundance of tintinnids. Mar Biol. 72: 79-87

Wada, M., Miyazaki, A., Fujii, T. (1985). On the mechanisms of diurnal vertical migration behaviour of Heterosigma akashiwo (Raphidophyceae). Plant Cell Physiol. 26: $431-436$

Wailes, G. H. (1939). Canadian Pacific Fauna. 1. Protozoa. Mastigophora. Univ. of Toronto Press

Whyte, J. N. C. (1991). The effects of Heterosigma akashiwo on juvenile chinook salmon. In: Forbes, J. R. (ed.) Pacific coast research on toxic marine algae. Can. Tech. Rep. Hydrogr. Ocean Sci. 135: 3-8

Wood, E. D., Armstrong, F. A. J., Richards, F. A. (1967). Determination of nitrate in seawater by cadmium-copper reduction to nitrite. J. mar. biol. Ass. U.K. 47: 23-31

Wright, J. L. C., Boyd, R. K., de Freitas, A. S. W., Falk, M. Foxall, R. A., Jamieson, W. D., Laycock, M. V., McCulloch A. W. Mclnnes, A. G., Odense, P., Pathak, V. P., Quinlan M. A., Ragan, M. A., Sim, P. G., Thibault, P., Walter, J. A., Gilgan, M., Richard, D. J. A., Dewar, D. (1989). Identification of domoic acid, a neuroexcitatory amino acid, in toxic mussels from eastern Prince Edward Island. Can. J. Chem. 67: $481-490$

Yamochi, S. (1989). Mechanisms for outbreak of Heterosigma akashiwo red tide in Osaka Bay. In: Okaichi, T., Anderson, D. M., Nemato, T. (eds.) Red tides: biology, environmental science, and toxicology. Elsevier, New York

Yasumoto, T. (1990). Marine microorganisms toxins - an overview. In: Granéli, E., Sundström, B., Edler, L., Anderson, D. M. (eds.) Toxic marine phytoplankton. Elsevier, New York, p. 3-8

Yasumoto, T., Oshima, Y., Sugarawa, W., Fukuyo, W., Oguri, H., Igarashi, T., Fujita, N. (1980). Identification of Dinophysis fortii as the causative organism of diarrhetic shellfish poisoning. Bull. Jap. Soc. scient. Fish. 46: 1405-1411

Manuscript first received: March 10,1993

Revised version accepted: August 16, 1993

This article was submitted to the editor 